\title{
Peningkatan Produksi Kacang Panjang (Vigna sinensis, L.) Melalui Pemberian Solid Pada Tanah Podsolik Merah Kuning (PMK)
}

\author{
Markus Sinaga dan Entumeng \\ Fakultas Pertanian Universitas Kapuas Sintang. \\ Email: ezarsinaga@gmail.com
}

\begin{abstract}
Abstrak: Meningkatkan produksi kacang panjang pada tanah yang kurang subur seperti tanah Podsolik Merah Kuning (PMK) dapat dilakukan dengan pemberian bahan organik seperti solid, karena dapat mengatasi kekurangan bahan organik dan unsur hara. Tujuan penelitian untuk mengetahui peningkatan produksi kacang panjang melalui pemberian solid pada tanah PMK. Mengetahui jumlah pemberian solid yang dapat meningkatkan produksi kacang panjang pada tanah PMK. Penelitian ini menggunakan metode percobaan lapangan, dan menggunakan Rancangan Acak Kelompok (RAK). Perlakuan pada penelitian ini adalah pemberian solid $(S)$ yang terdiri dari lima taraf, yaitu: tanpa pemberian solid $\left(\mathrm{S}_{0}\right), 1,3 \mathrm{~kg}$ solid/ $\mathrm{m}^{2}\left(\mathrm{~S}_{1}\right), 2,6 \mathrm{~kg} \operatorname{solid} / \mathrm{m}^{2}\left(\mathrm{~S}_{2}\right), 3,9 \mathrm{~kg} \operatorname{solid} / \mathrm{m}^{2}\left(\mathrm{~S}_{3}\right)$, dan $4,2 \mathrm{~kg}$ solid $/ \mathrm{m}^{2}\left(\mathrm{~S}_{4}\right)$. Data hasil pengamatan dianalisis dengan analisis ragam dan dilanjutkan dengan uji BNJ. Hasil penelitian menunjukkan bahwa pemberian solid tidak meningkatan berat berangkasan, tetapi meningkatkan jumlah dan berat polong. Pemberian 2,4 kg solid dapat meningkatkan produksi kacang panjang pada tanah PMK, rata-rata jumlah polong 372,63 per tanaman dan berat polong rata-rata 438,37 gram per tanaman.
\end{abstract}

Kata kunci: PMK, Solid, Kacang Panjang, Produksi

\section{PENDAHULUAN}

Produksi kacang panjang (Vigna sinensis, L) berdasarkan hasil rekomendasi East West Seed Indonesia (2020) dapat mencapai 25-35 ton ha- ${ }^{-1}$, sedangkan hasil penelitian Puslitbanghorti (2018) potensi produksi kacang panjang mencapai 30 ton $\mathrm{ha}^{-1}$. Produksi ini jauh lebih tinggi dibandingkan dengan produksi beberapa daerah di Provinsi Kalimantan Barat khususnya Kabupaten Sekadau hanya 2 ton ha ${ }^{-1}$ rendahnya produksi ini disebabkan oleh beberapa faktor salah satunya adalah lahan karena sebagian besar adalah tanah PMK, tanah ini diketahui rendah bahan organik dan unsur hara. Prasetyo dan Suriadikarta (2006) menyatakan bahwa tanah PMK umumnya mempunyai nilai kejenuhan basa rendah, kapasitas tukar kation kurang rendah, reaksi tanah umumnya masam hingga sangat masam ( $\mathrm{pH} 5$ ?3,10). Salah satu upaya meningkatkan produksi tanaman pada tanah PMK adalah menambah bahan organik dan unsur hara dengan cara memberikan solid.

Solid adalah limbah dari pengolahan kelapa sawit, secara umum Solid memiliki kandungan unsur hara seperti $\mathrm{N}, \mathrm{P}, \mathrm{K}, \mathrm{Mg}$ dan Ca. Widjaja dan Utomo (2005) menyatakan bahwa padatan solid memiliki kandungan bahan kering $81,65 \%$ yang didalamnya terdapat protein kasar $12,63 \%$; serat kasar 9,98\%; lemak kasar 7,12\%; kalsium 0,03\%; fosfor $0,003 \%$; hemiselulosa $5,25 \%$; selulosa $26,35 \%$ dan energy $3.454 \mathrm{kkal} / \mathrm{kg}$.

Hasil penelitian Lubis (2019) pemberian 20 ton solid decanter $\mathrm{ha}^{-1}$ pada tanaman padi dapat meningkatkan panjang tanaman umur 12-15 MST, jumlah anakan, luas daun bendera, jumlah malai, dan produksi gabah per plot. Damanik, dkk (2017) membuktikan bahwa pemberian solid kelapa sawit 26 ton ha ${ }^{-1}$ dan NPK $200 \mathrm{~kg} \mathrm{ha}^{-1}$ dapat memberikan hasil terbaik tanaman kacang tanah yag diketahui pada pengamatan jumlah polong pertanaman, persentase polong bernas, bobot 100 biji dan bobot biji.

Penelitian ini bertujuan untuk mengetahui (1) Peningkatan produksi kacang panjang melalui pemberian solid pada tanah PMK. (2) Jumlah pemberian solid yang dapat meningkatkan produksi kacang panjang pada tanah PMK. 


\section{METODE PENELITIAN}

Penelitian ini dilakukan dengan menggunakan metode percobaan lapangan, dan menggunakan Rancangan Acak Kelompok (RAK). Perlakuan pada penelitian ini adalah pemberian solid (S) yang terdiri dari lima taraf, yaitu: tanpa pemberian solid $\left(\mathrm{S}_{0}\right), 1,3 \mathrm{~kg}$ solid $/ \mathrm{m}^{2}$

\section{HASIL DAN PEMBAHASAN}

\section{Hasil Penelitian}

Hasil penelitian diketahui bahwa produksi kacang panjang melalui pemberian solid pada tanah
$\left(\mathrm{S}_{1}\right), 2,6 \mathrm{~kg}$ solid $/ \mathrm{m}^{2}\left(\mathrm{~S}_{2}\right), 3,9 \mathrm{~kg}$ solid $/ \mathrm{m}^{2}\left(\mathrm{~S}_{3}\right)$, dan $4,2 \mathrm{~kg}$ solid $/ \mathrm{m}^{2}\left(\mathrm{~S}_{4}\right)$. Jumlah tanaman percobaan dalam penelitian ini adalah 6 tanaman x 5 taraf pemberian Solid x 5 ulangan = 150 tanaman, sedangkan yang tanaman diamati adalah seluruh tanaman percobaan. Data hasil pengamatan dianalisis dengan analisis ragam dan dilanjutkan dengan uji BNJ.

PMK menunjukkan bahwa adanya peningkatan secara nyata pada jumlah polong dan berat polong per tanaman, tetapi tidak nyata pada berat berangkasan seperti terlihat pada Tabel 1 .

Tabel 1. Analisis Ragam Produksi Kacang Panjang Melalui Pemberian Solid

\begin{tabular}{|c|c|c|c|c|c|c|}
\hline \multicolumn{7}{|c|}{ Berat Berangkasan $(\mathrm{g})$} \\
\hline \multirow[b]{2}{*}{ SK } & \multirow[b]{2}{*}{ DB } & \multirow[b]{2}{*}{ JK } & \multirow[b]{2}{*}{$\mathrm{KT}$} & \multirow[b]{2}{*}{ F hitung } & \multicolumn{2}{|c|}{ F tabel } \\
\hline & & & & & 0,05 & 0,01 \\
\hline Ulangan & 4 & 30950,52 & 7737,63 & $1,06^{\mathrm{ns}}$ & 3,01 & 4,77 \\
\hline Perlakuan & 4 & 20702,56 & 5175,64 & $0,71^{\mathrm{ns}}$ & 3,01 & 4,77 \\
\hline Galat & 16 & 117235,64 & 7327,23 & & & \\
\hline Total & 24 & 168888,72 & & $k k=$ & 32.40 & \\
\hline \multicolumn{7}{|c|}{ Jumlah Polong } \\
\hline Ulangan & 4 & 42243,80 & 10560,95 & $1,39^{\mathrm{ns}}$ & 3,01 & 4,77 \\
\hline Perlakuan & 4 & 99509,58 & 24877,40 & $3,27^{*}$ & 3,01 & 4,77 \\
\hline Galat & 16 & 121705,30 & 7606,58 & & & \\
\hline Total & 24 & 263458,68 & & $k k=$ & 29,09 & \\
\hline \multicolumn{7}{|c|}{ Berat Polong $(\mathrm{g})$} \\
\hline Ulangan & 4,00 & 12327,72 & 3081,93 & $0,83^{\mathrm{ns}}$ & 3,01 & 4,77 \\
\hline Perlakuan & 4,00 & 79420,71 & 19855,18 & $5,37^{* *}$ & 3,01 & 4,77 \\
\hline Galat & 16,00 & 59143,73 & 3696,48 & & & \\
\hline Total & 24,00 & 150892,17 & & $k k=$ & 16,90 & \\
\hline
\end{tabular}

Sumber: Analisa Data, 2020.

Hasil analisis ragam pada Tabel 1 menunjukkan bahwa ada peningkatan produksi kacang panjang melalui pemberian solid pada tanah PMK, hasil uji BNJ disaji pada Tabel 2.

Tabel 2. Hasil Uji BNJ Pemberian Solid Terhadap Jumlah dan Berat Polong (g)

\begin{tabular}{cccc}
\hline \multicolumn{1}{c}{ Jumlah Polong (polong) } & \multicolumn{2}{c}{ Berat Polong $(\mathrm{g})$} \\
\hline $\mathrm{S}_{0}$ & $220,70 \mathrm{a}$ & $\mathrm{S}_{0}$ & $268,30 \mathrm{a}$ \\
$\mathrm{S}_{1}$ & $239,47 \mathrm{ab}$ & $\mathrm{S}_{1}$ & $339,73 \mathrm{~b}$ \\
$\mathrm{~S}_{3}$ & $297,93 \mathrm{~b}$ & $\mathrm{~S}_{3}$ & $362,30 \mathrm{~b}$ \\
$\mathrm{~S}_{2}$ & $368,33 \mathrm{bc}$ & $\mathrm{S}_{2}$ & $390,30 \mathrm{bc}$ \\
$\mathrm{S}_{4}$ & $372,63 \mathrm{c}$ & $\mathrm{S}_{4}$ & $438,37 \mathrm{c}$ \\
\hline BNJ $0,05=70,64$ & & BNJ $0,05=49,25$ & \\
BNJ $0,01=90.53$ & & BNJ $0.01=63,11$ & \\
\hline
\end{tabular}

Sumber: Analisa Data, 2020. 
Hasil uji BNJ pada Tabel 1 juga dapat dijelaskan pada Gambar 1.

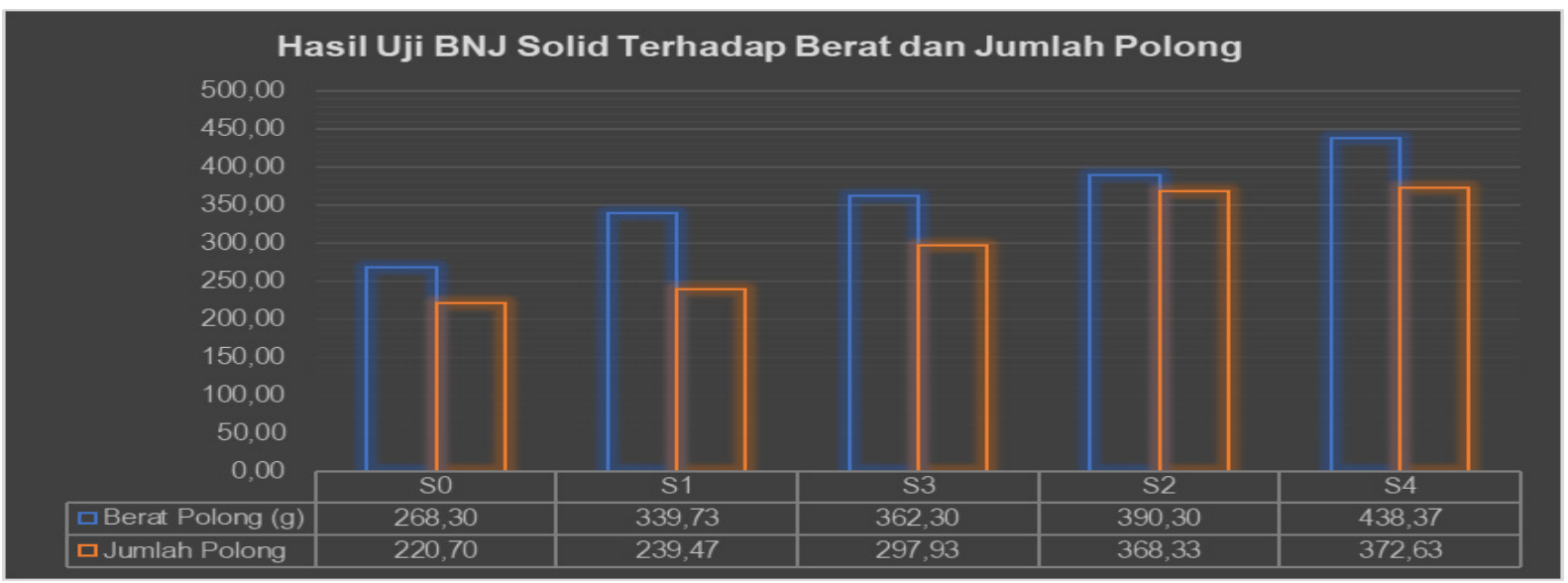

Gambar 1. Hasil Uji BNJ Solid Terhadap Berat dan Jumlah Polong

\section{Pembahasan}

Pemberian solid berpengaruh terhadap jumlah polong dan berat polong kacang panjang pada tanah PMK, hal ini disebabkan karena solid berperan dalam meningkatkan bahan organik tanah PMK serta menyumbang unsur hara bagi tanah sehingga pembentukan bunga dan polong kacang panjang meningkat. Menurut Gaur (2010) dalam Panjaitan, dkk (2018) bahan organik berperan dalam perbaikan sifat fisik, biologi, dan kimia tanah diantaranya granulasi, memperbaiki aerasi tanah dan meningkatkan kemampuan menahan air, meningkatkan aktivitas mikroorganisme yang berperan pada fiksasi nitrogen dan transfer hara $\mathrm{N}, \mathrm{P}$ dan $\mathrm{S}$, meningkatkan kapasitas tukar kation sehingga dapat mempengaruhi serapan hara oleh tanaman.

Hasil uji BNJ seperti terlihat pada Tabel 2 dan Gambar 1 diketahui bahwa pemberian 4,2 kg solid $\left(\mathrm{S}_{4}\right)$ meningkatkan jumlah polong dan berat polong hal ini diduga karena solid menambah bahan orgaik serta mampu memperbaiki sifat fisik tanah seperti menambah kualitas porositas tanah dan kemampuan tanah dalam menahan air. Pemberian solid juga memperbaiki kimia tanah PMK seperti bertambahnya unsur hara N, P dan K. Membaiknya kondisi tanah berpengaruh terhadap biologi dalam tanah karena tersedianya bahan makanan bagi mikroorganisme tanah yang pada akhirnya berpengaruh terhadap lepasnya unsur-unsur hara yang sebelumnya terikat oleh koloid tanah sehingga tersedia bagi tanaman kacang panjang. Peningkatan jumlah polong dan berat polong disebabkan karena PIPER No. 31 Volume 16 Oktober 2020 aktivitas fotosinetsis meningkat dan juga meningkatkan fotosintat yang dihasilkan, lalu ditransfer kebiji yang mana biji tanaman bertindak dan berfungsi sebagai cadangan makanan. Semakin banyak candangan makanan di dalam biji menyebabkan polong juga menjadi berat.

\section{KESIMPULAN}

Hasil penelitian disimpulkan: (1) Pemberian solid tidak meningkatan berat berangkasan, tetapi meningkatkan jumlah dan berat polong. (2) Pemberian 2,4 $\mathrm{kg}$ solid atau 24 ton ha ${ }^{-1}$ dapat meningkatkan produksi kacang panjang pada tanah PMK, rata-rata jumlah polong 372,63 per tanaman dan berat polong rata-rata 438,37 gram per tanaman atau $2,63 \mathrm{~kg} / \mathrm{m}^{2}$ setara dengan 26,30 ton $\mathrm{ha}^{-1}$.

\section{SARAN}

Saran pada penelitian ini yaitu: (1) Meningkatkan produksi kacang panjang pada tanah PMK dapat diberikan solid sebanyak 24 ton ha' ${ }^{-1}$. (2) Perlu dilakukan penelitian lanjutan dengan menggunakan solid diatas 24 ton ha ${ }^{-1}$.

\section{DAFTAR PUSTAKA}

Damanik, D.S., Murniati., dan Isnaini. 2017. Pengaruh Pemberian Solid Kelapa Sawit Dan NPK Terhadap Pertumbuhan Dan Produksi Tanaman Kacang Tanah (Arachis hypogaea L.). JOM Faperta Vol.4 No.2 Oktober 2017. 
East West Seed Indonesia. 2020. Deskripsi Kacang Panjang Varietas Kanton Tavi. http://www.panahmerah.id.

Lubis, F. Z. 2019. Respons Pertumbuhan dan Produksi Beberapa Varietas Padi Gogo Terhadap Pemberian Berbagai Bahan Organik. http://repositori.usu.ac.id/handle/ 123456789/15930. Diakses 10 Januari 2020.

Panjaitan, I.A., S. Hasibuan., dan Safruddin. 2018. Pengaruh Pemberian Pupuk Solid Padat Dan Pupuk NPK Terhadap Pertumbuhan Dan Produksi Tanaman Jagung (Zea mays saccharata Sturt.). BERNAS Agricultural Research JournalVolume 14 No 3, 2018.
Prasetyo, B.H., dan Suriadikarta, D.A. 2006. Karakteristik, Potensi, dan Teknologi Pengelolaan Tanah Ultisol Untuk Pengembangan Pertanian Lahan Kering di Indonesia. Bogor: Jurnal Litbang Pertanian, Nomor: 25 edisi ke-2.

Puslitbanghorti. 2018. Budidaya Tanaman Kacang Panjang. http:// hortikultura.litbang.pertanian.go.id.

Widjaja, F dan B.N. Utomo,. 2005. Pemanfaatan Limbah Pengolahan Minyak Kelapa Sawit yang Berupa Solid untuk Pakan Ternak (Sapi, Domba Dan Ayam Potong). Success Story Pengembangan Teknologi Inovatif Spesifik Lokasi. Badan Litbang Pertanian. 